\title{
MILKER'S NODULE
}

Swetha Balaji ${ }^{1}$, C. R. V. Narasimhalu ${ }^{2}$

\section{HOW TO CITE THIS ARTICLE:}

Swetha Balaji, C. R. V. Narasimhalu. "Milker's Nodule". Journal of Evolution of Medical and Dental Sciences 2015; Vol. 4, Issue 69, August 27; Page: 12081-12082, DOI: 10.14260/jemds/2015/1740

ABSTRACT: Milker's nodule is a skin infection caused by DNA virus named parapox. Humans are prone for this infection when they come in contact with the cattles which are infected. ${ }^{[1]} \mathrm{A}$ case of 23 years old male came with complaints of raised skin lesions on the sides of fingers of right hand for past 1 week. Initially there was a single lesion later it increased in size and number to attain the present state. There is no history of itching, contact with chemicals, burning sensation and drug intake. There is a history of milking of cows for past 10 years. No history of any disease in cattles.

No history of similar illness in family or any other lesion elsewhere in the body.

KEYWORDS: Milker's nodule, Parapox virus, Skin, Cattles.

MESHTERMS: Milker's nodule, Cutaeneous, Infected cattles, Parapox.

INTRODUCTION: A cutaeneous infection acquired from the teats of infected cows- Milker's nodule. It is more common in people handling cattles.[2] Vetenarians who treat the infected animals also get this infection. The causative agent is paravaccina/ parapox virus which is DNA virus by nature. A duration of 5 to 14 days is necessary for signs like development of papules on the digits progressing to erythematous nodules to occur. ${ }^{[3]} \mathrm{A}$ minimal number of patients have lymphangitis. One point which makes a clinician to think this diagnosis is the exposure to cattles. Infected cattles manifest the disease in the form of ring sores. Apart from clinical history and examination, diagnosis is confirmed by methods like enzyme assays. Though it is self-limiting and not a common condition, it should be considered when history and signs are for it and diagnostic methods holds on.[4]

DISCUSSION: A benign skin lesion seen in the fingers and affects humans who handle cattles which are infected by paravaccina virus. Since this infection is acquired by the activity of milking this is seen on the fingers. In this patient, history and clinical examination were pointing towards this particular diagnosis. This was supported by diagnostic methods. The patient was given topical corticosteroid (Clobestol) and patient was followed regularly to see the improvement. Lesions gradually regressed due to the treatment. Patient was asked to stay away from milking for few weeks. This is not a danger disease to be worried for still this should be treated once the diagnosis is clinched.

\section{REFERENCES:}

1. IADVL, Textbook of Dermatology. $3^{\text {rd }}$ ed., 1;2012:363.

2. Rook's Textbook of Dermatology, $8^{\text {th }}$ ed., Vol. 2, 2010;33:10-11.

3. Fitzpatrick's Dermatology in general medicine, $8^{\text {th }}$ ed., vol. 2, 2012; 2414-2415.

4. Werchniak AE et al: Milker's nodule ina healthy young woman. J Am Acad Dermatol 2003; 49(5): 910-911 


\section{CASE REPORT}
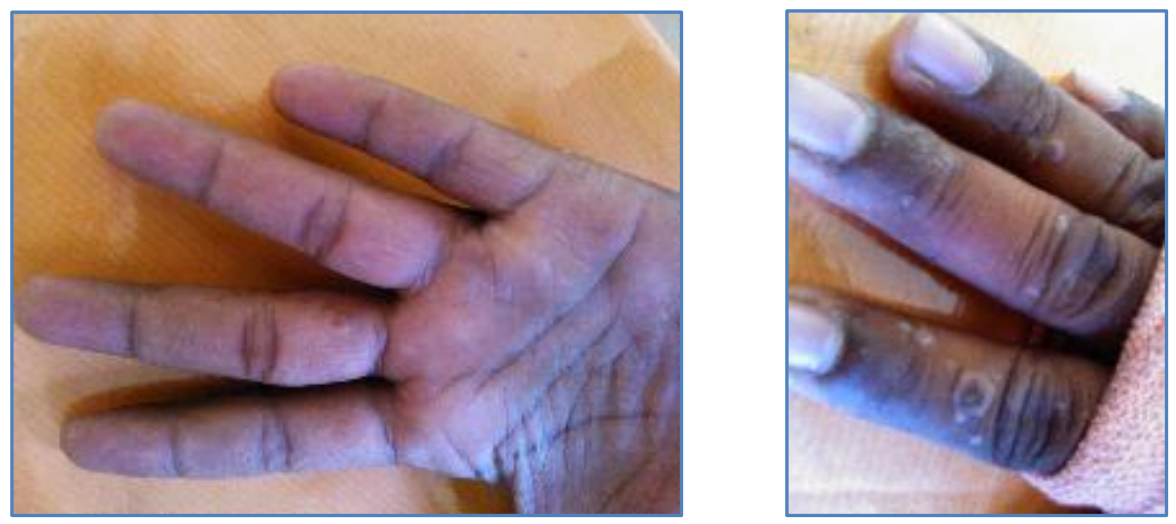

Fig. 1: Lesion in the middle finger

Fig. 2: Development of papules over the fingers

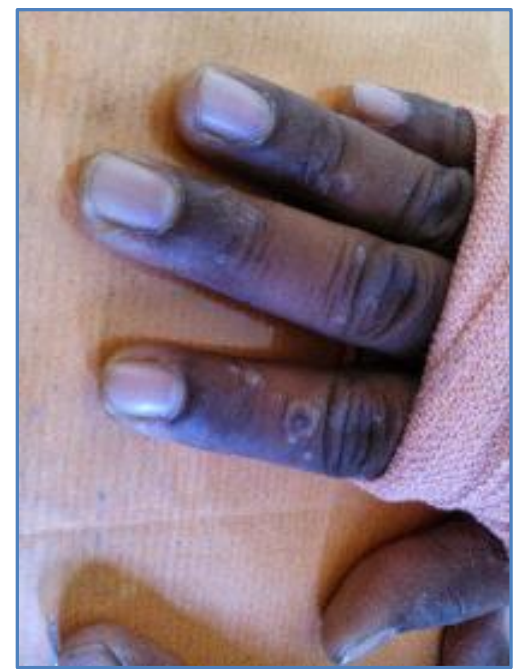

Fig. 3: Papules seen over the fingers

\section{AUTHORS:}

1. Swetha Balaji

2. C. R. V. Narasimhalu

\section{PARTICULARS OF CONTRIBUTORS:}

1. CRRI.

2. Associate Professor, Department of Dermatology, Saveetha Medical College \& Hospital.

\section{FINANCIAL OR OTHER} COMPETING INTERESTS: None
NAME ADDRESS EMAIL ID OF THE CORRESPONDING AUTHOR:

Dr. Swetha Balaji,

No: 13/A Arcot Road,

Ranipet-632401.

E-mail: n.b.swetha@gmail.com

Date of Submission: 24/03/2015.

Date of Peer Review: 25/03/2015.

Date of Acceptance: 26/06/2015.

Date of Publishing: 26/08/2015. 